\title{
Analysis and insights into written competence of clil and non-clil programs in tertiary context
}

\author{
Nozimakhon URALOVA ${ }^{1}$ \\ Yeoju Technical Institute in Tashkent
}

\begin{tabular}{l} 
ARTICLE INFO \\
\hline Article history: \\
Received May 2021 \\
Received in revised form \\
20 May 2021 \\
Accepted 15 June 2021 \\
Available online \\
15 July 2021 \\
\hline
\end{tabular}

Keywords:

written competence,

fluency,

accuracy,

lexical complexity,

grammar complexity,

cognitive skills.
ABSTRACT

In 2020 a new faculty was established at Yeoju Technical Institute in Tashkent. This faculty is the first in Uzbekistan that teaches learners dual-focused Content and Language Integrated Learning (CLIL) approach. The research was conducted within one academic year (2 semesters), in experimental and control groups that include CLIL and non-CLIL language learners. The chosen module was Introduction to Academic Writing that compares the writing performance of CLIL and non-CLIL students in terms of 3 dimensions: fluency, accuracy, and complexity of academic writing. The result of the research revealed that the CLIL group showed better results compared with non-CLIL students regarding the frequent usage of academic vocabulary, complexity in structure, and content of writing, demonstrating a more critical approach to the assigned topics.

2181-1415/C) 2021 in Science LLC.

This is an open access article under the Attribution 4.0 International (CC BY 4.0) license (https://creativecommons.org/licenses/by/4.0/deed.ru)

\section{Oliy ta'lim kontekstida clil va non-clil dasturlarining yozma vakolatlarini tahlil qilish va tushunish}

\author{
Kalit so'zlar: \\ yozma kompetensiya, \\ ravonlik, \\ aniqlik, \\ leksik murakkablik, \\ grammatik murakkablik, \\ bilim qobiliyatlari.
}

\begin{abstract}
ANNOTATSIYA
2020-yilda Toshkentdagi Yeoju texnika institutida yangi fakultet ochildi. Ushbu fakultet O'zbekistonda birinchi bo'lib talabalarga predmet va tillarni integratsiyalashgan o'qitishning ikki yo'naltirilgan yondashuvini (CLIL) o'rgatmoqda. Tadqiqotlar bir o'quv yili davomida (2 semestr) eksperimental va nazorat guruhlarida o'tkazildi, ular tarkibiga CLIL tillarini o'rganadigan va CLILni yaxshi bilmaydigan talabalar kiritildi. Tanlangan modul CLIL va CLIL bo'Imagan talabalarning yozma
\end{abstract}

\footnotetext{
${ }^{1}$ EFL lecturer, Yeoju Technical Institute in Tashkent, Uzbekistan.

E-mail: nozimakhon1988@gmail.com.
} 
ko'nikmalarini uchta parametr bilan taqqoslaydigan akademik yozuvga kirish edi: ravonlik, aniqlik va akademik yozuvning murakkabligi. Tadqiqot natijalari shuni ko'rsatdiki, CLIL guruhi CLIL-da o'qimagan talabalar bilan taqqoslaganda, akademik so'z birikmalaridan tez-tez foydalanish, yozma tarkibning murakkabligi va mazmuni bilan bog'liq bo'lib, ushbu mavzularga nisbatan ko'proq tanqidiy yondashuvni namoyish etdi.

\section{Анализ и понимание письменной компетенции программ clil и non-clil в контексте высшего образования}

\author{
Ключевые слова: \\ письменная компетенция, \\ беглость, \\ точность, \\ лексическая сложность, \\ сложность грамматики, \\ когнитивные навыки.
}

\begin{abstract}
АННОТАЦИЯ
В 2020 году в Техническом институте Ёджу в Ташкенте был открыт новый факультет. Этот факультет является первым в Узбекистане, который обучает учащихся двухфокусному подходу к предметному и языковому интегрированному обучению (CLIL). Исследование проводилось в течение одного учебного года (2 семестра) в экспериментальных и контрольных группах, в которые входили студенты, изучающие языки CLIL и не владеющие CLIL. Выбранный модуль представлял собой введение в академическое письмо, которое сравнивает письменные навыки студентов CLIL и не-CLIL по трем параметрам: беглость, точность и сложность академического письма. Результат исследования показал, что группа CLIL показала лучшие результаты по сравнению со студентами, не обучающимися в CLIL, в отношении частого использования академической лексики, сложности структуры и содержания письма, демонстрируя более критический подход к заданным темам.
\end{abstract}

\section{INTRODUCTION}

In recent years Content and Language Integrated Learning (CLIL), an approach in which subjects are taught and learnt in a language which is not a mother tongue of learners, has become increasingly widespread in private and state school sectors in Europe. This educational approach is believed to bring many benefits to learners' linguistic and metalinguistic abilities, enhance their motivational intensity, levels of concentration and problem-solving skills. According to Eurydice Survey (2006), nearly all European countries offer CLIL curriculum, including Italy and Austria, which have made CLIL mandatory in schools. The major reason for this is " $1+2$ principle, which encapsulated in the European Commission's White Paper on Education and Training, which requires European citizens to have a competence being able to speak in two languages and incorporating this into national curricula" (Lorenzo, 2007). However, CLIL programs have been varying across different contexts, being implemented not only in secondary schools, but also in higher institutions. This study was conducted at university level, and encompasses the analysis of both linguistic and cognitive changes of $1^{\text {st }}$ year students who are being taught inCLIL and non-CLIL context. In terms of linguistic competence, the research focuses specifically on writing process, narrowing the scope to correlation 
between learners' higher order thinking (HOT) skills and completing writing tasks successfully. According to Coyle and Hood (2010) CLIL goes beyond enhancing communicative competence of learners, but also turns students into active learners who gains knowledge through "the process of inquire" and "active cognitive engagement". Lorenzo (2007) highlights that CLIL learners show "greater gains" than their mono-lingual peers in terms of lexico -grammatical and discourse levels. As a subset of L2 learners' language competences, written competence puts more emphasis on language specific abilities such as "the use of language a range of vocabulary and syntactic structures" (Wolfe-Quintero, Inagaki and Kim, 1998). Most of the research in second language acquisitions has revealed that among four linguistic competences, writing requires the usage of more HOT skills. Bereiter and Scardamalia (1987) postulated that in comparison with other linguistic skills (reading, speaking, and listening) metacognitive control and analytical thinking are the most critical in writing. Larsen-Freeman (2006) conceptualized writing as a complex dynamic process of language development. Thus, being a subset of language competences, writing is also complex and characterized by these three dimensions:

- Fluency

- Accuracy

- Complexity

Wolfe-Quintero, Inagaki and Kim (1998) conducted the research which revealed that fluency, accuracy, grammar, and lexical complexity are those aspects of writing which can give an accurate information on writer's language proficiency. The study analyzes those dimensions and intends to shed some light on the following research questions:

- How will CLIL students' written performance improve compare to that of their non-CLIL counterparts?

- What will the difference be between the measures in the areas of fluency, accuracy, and complexity?

\section{METHODOLOGY}

Participants. The participants were 50 students of Yeoju Technical Institute in Tashkent. Experimental CLIL group comprised 24 students and non-CLIL control group comprised 26 students, who had CEFR B1 level. Both groups started their course from October, and observed within 6 months. The CLIL group received 4 hours a week CLIL instruction in science and literature through English and 3 hours formal instruction in EFL, whilst the control group received 4 hours a week of formal instruction in EFL. Both groups were exposed to writing equal hours of writing instruction, yet the control group had brief writing assignments, specifically on general topics. Regarding the experimental group, its compositions were more subject-specific and a bit longer. Both groups' writing works were assessed according to the analytical rubric and neither groups did not receive a personalized feedback from their language instructors.

Instruments. At the beginning of the course both groups were given diagnostic tests of writing to measure their writing dimensions. To compare the level and linguistic competences, a standardized English Test was administered to the participants prior experiment. Each 4 weeks participants were gauged with the help of various writing tasks, ranging from paragraph writing to narrative and argumentative essay writing. These tasks were designed in alliance with the topics given in their syllabus, and the learners were 
familiar how to write them. Before completing the task, students were received a formal instruction and practiced the writing topics during their classes. During the test, detailed oral and written instructions were given to ensure that the learners understood what they were requested to write.

Data collection and analysis. The participants were selected according to the language proficiency test. Participants who were lower than B1 level were excluded from the experiment. The selected students were given a diagnostic test at the beginning of the semester which was assigned to write a paragraph on the topic "The influence of social media on people's relationships". The participants were given 30 minutes to write their composition. The paragraphs were assessed in terms of grammar and lexis. The maximum score was 20. Majority of learner did not perform well, overall percentage of collected scores was 33 and 34,5 for experimental and control groups respectively (table 1). Regarding methodology used in the groups, both contexts followed communicative language teaching (CLT). Formal instructions mainly focused on grammar and language forms, implementing "garden path" technique (Tomasello \& Herron, 1989). As Tomasello \& Herron (1989) pointed out this technique means "giving students information about grammar construction without giving them a full picture". Writing activities were the part of the curriculum in both programs. However, the experimental group received more language input and exposure to the target language. Within 4 weeks students practiced a new writing topic and were requested to pass the test. Their work was measured following Wolfe-Quintero et al. (1998), administering fluency, accuracy, grammatical and lexical complexity. Fluency was measured by counting the total number of words, whereas accuracy was administered by dividing total number of error-free sentences to total number of sentences. In terms of grammar complexity, total number of clauses were divided by total number of sentences. To measure a lexical complexity, the level of used tokens was checked (Cambridge Advanced Dictionary). The scoring procedure was conducted using analytical 5-scale rubric, comprising Content, Organization, Lexical Resource and Mechanics (Bulte and Housen, 2014). Moreover, learners were analyzed from a deductive perspective, which is a theoretical approach of gauging students' strategic and socio-linguistic competences (Swain,2000).

\section{RESULTS AND DISCUSSION}

The results revealed significant differences between the CLIL and non-CLIL groups. The CLIL group outperformed their non-CLIL counterparts in the quality of content of their essays and arguments presented. Alongside with this, CLIL program group showed a dramatic improvement in terms of three writing dimensions, except grammatical competence which was found to have almost equal percentage with more error-free sentences. Nevertheless, the experimental groups' writing fluency was much higher, exceeding total number of words and outperforming the control group in terms of sentence length. As regards lexical complexity, CLIL group had much better result than non-CLIL group. The lexis used by CLIL group was improving by each task, becoming more academic, and at a higher level (B2, C1). In comparison with non-CLIL group, CLIL program group showed much better analytical, problem solving and strategic skills. The quality of ideas of their argumentative essays was directed to more broader concepts and the controlling ideas were also supported thoroughly using concessions and strong rebuttals. While non-CLIL groups showed poor logical organization, unity, and coherence, CLIL group students' essays were more coherent, smooth, logically organized and being corresponded 
to good-to-average level at every research time. CLIL students progressed significantly in writing over time rather than non-CLIL students.

Table 1.

The Results of writing performance of CLIL and non-CLIL program groups

\begin{tabular}{|c|c|c|}
\hline \multicolumn{2}{|c|}{ CLIL group } & non-CLIL group \\
\hline Diagnostic writing & $33 \%$ & $34,5 \%$ \\
\hline Writing test 1 & $44 \%$ & $38 \%$ \\
\hline Writing test 2 & $52 \%$ & $42 \%$ \\
\hline Writing test 3 & $64 \%$ & $52 \%$ \\
\hline Writing test 4 & $73 \%$ & $58 \%$ \\
\hline Writing test 5 & $84 \%$ & $62 \%$ \\
\hline Writing test 6 & $92 \%$ & $78 \%$ \\
\hline
\end{tabular}

Table 2.

The Results of writing competences of CLIL and non-CLIL groups

\begin{tabular}{|c|c|c|}
\hline \multicolumn{2}{|c|}{ CLIL group } & non-CLIL group \\
\hline Fluency & $91 \%$ & $72 \%$ \\
\hline Accuracy & $87 \%$ & $71 \%$ \\
\hline Grammar complexity & $85 \%$ & $83 \%$ \\
\hline Lexical complexity & $90 \%$ & $72 \%$ \\
\hline
\end{tabular}

This research investigated and compared the written competence of CLIL and nonCLIL program learners. In the general quality of essays, CLIL group outperformed non-CLIL group in all measures of writing and supports the results of previously conducted studies (Naves and Victori, 2010; Lorenzo and Ridriguez, 2014). The results of writing measures and the general quality of written works revealed that learning content in English enhanced not only overall linguistic competences, but also the higher order thinking of students.

\section{CONCLUSION}

Although at the beginning of the semester, both group learners showed a relatively low results in diagnostic writing test, during their studies they improved their writing skill gradually. CLIL program exerted more positive influence on writing dimensions, since in CLIL programs students were more exposed to the English language. Moreover, the CLIL program implemented many aspects of Communicative Language Teaching and put more emphasis on academic content. Integrating both content and language goals tend to provide more suitable contexts to develop written discourse. Subsequently, these aspects provide necessary conditions for more effective learning and developing writing competence. In comparison with the control group, the experimental group showed much better result in terms of writing fluency, accuracy, grammar complexity and lexical complexity. CLIL groups used more higher level and academic lexis and more complex grammar rather than their non-CLIL counterparts. Regarding the content of their writing works, the CLIL group showed more critical approach, providing a better analysis of the topic. 


\section{REFERENCES:}

1. Eurydice. 2006. Content and Language Integrated Learning at School in Europe. Eurydice European Unit

2. Bereiter C., \& Scardamalia M. (1987). The Psychology of Written Composition. Hillsdale, NJ Lawrence Erlbaum Associates.

3. Bulté B., \& Housen A. (2014): "Conceptualizing and measuring short-term changes in L2 writing complexity", Journal of Second Language Writing 26. - PP. 42-65.

4. Coyle D., Hood P., \& Marsh D. (2010). CLIL: Content and Language Integrated Learning. Cambridge: Cambridge University Press.

5. Larsen-Freeman D. (2006). The emergence of complexity, fluency, and accuracy in the oral and written production of five Chinese learners of English, Applied Linguistics 27(4). - PP. 590-619.

6. Lorenzo F. (2007). An analytical framework of language integration in L2 contentbased courses. Language and Education 21. - PP. 503-13.

7. Lorenzo F., Casal S. Moore P. (2010). The effects of content and language integrated learning in European education: key findings from the Andalusian sections evaluation report. Applied Linguistics, 31. - PP. 418-442.

8. Navés T., \&Victori M. (2010). CLIL in Catalonia: An Overview of Research Studies, in David Lasagabaster and Yolanda Ruiz de Zarobe (eds.), CLIL in Spain: Implementation, Results and Teacher Training. Newcastle: Cambridge Scholars Publishing. - PP. 30-54.

9. Swain M. (2000). The output hypothesis and beyond: Mediating acquisition through collaborative dialogue. In J.P. Lantolf (Ed.), Sociocultural theory and second language learning. Oxford: Oxford University Press.

10. Tomasello M., \& Herron C. (1989). Feedback for language transfer errors: The garden path technique. Studies in Second Language Acquisition, 11(4). - PP. 385-395.

11. Wolfe-Quintero K., Inagaki Sh., \& Kim H. (1998): Second Language Development in Writing: Measures of Fluency, Accuracy, and Complexity. Hawai'i: University of Hawai'i at Manoa. 